\title{
Dennettia tripetala Combats Oxidative Stress, Protein and Lipid Dyshomeostasis, Inflammation, Hepatic Injury, and Glomerular Blockage in Rats
}

\author{
Sylvia Oghogho Omage ${ }^{1}$, Noghayin E. Jerry Orhue ${ }^{1}$, and Kingsley Omage ${ }^{2}$ \\ ${ }^{1}$ Department of Biochemistry, Faculty of Life Sciences, University of Benin, Benin City, Edo State 300213, Nigeria \\ ${ }^{2}$ Department of Biochemistry, College of Health Sciences, School of Basic Medical Sciences, Igbinedion University Okada, \\ Benin City, Edo State 302110, Nigeria
}

\begin{abstract}
Dennettia tripetala, better known as 'pepperfruit', is a medicinal plant consumed in West Africa. D. tripetala possesses strong antioxidant properties and contains uvariopsine, an alkaloid which improves bile secretion and liver function. In the present study, the ethanolic extract of $D$. tripetala fruits was tested for its ability to alleviate pathophysiological conditions bordering on oxidative stress, including protein and lipid dyshomeostasis, inflammation, and hepatic and glomerular injury. Male albino Wistar rats were administered carbon tetrachloride twice a week for two weeks, and the ethanolic extract of $D$. tripetala fruits was administered from days $8 \sim 14$. The serum, liver, and kidneys of the rats were then subjected to biochemical assays and imaging. The extract restored the activities of liver marker enzymes in serum and the concentrations of lipids and proteins in both circulation and the liver to normal. The extract also restored the activities of antioxidant enzymes in liver and kidneys, and the concentrations of urea and creatinine in the blood. The extract also repaired the altered structures of the liver and kidney. Overall, D. tripetala elicited strong medicinal effects in rats. This study showed that the fruits of $D$. tripetala contain substances that could be extracted or synthesized for use in drugs for the treatment of liver and kidney disease.
\end{abstract}

Keywords: antioxidant, carbon tetrachloride, Dennettia tripetala, hepatorenal damage, oxidative stress

\section{INTRODUCTION}

Dennettia tripetala (pepperfruit) is a fruit eaten in the Western parts of Africa. D. tripetala possesses a spicy taste, which endears it to the inhabitants of this region, who both consume it as a fruit and use it to season foods including zobo, a local drink made from the flowers of $\mathrm{Hi}$ biscus sabdariffa (Ihemeje et al., 2013). D. tripetala is also consumed for medicinal purposes and used for food preservation (Okolie et al., 2014; Iseghohi, 2015). A number of scientific experiments have characterized the properties and potentials of $D$. tripetala, which have been extensively reviewed by Iseghohi (2015). Other experiments on $D$. tripetala have since been conducted, a number of which are mentioned below.

In 2016, the components of the essential oil of D. tripetala fruits were characterized using gas chromatography mass spectrometry (Okoh et al., 2016). The authors also studied the antioxidant and bactericidal properties of the oil to show that it possesses antioxidant properties in vitro and exhibits strong bacteriostatic effects on common multi-drug resistant bacterial strains (Okoh et al., 2016). In 2017, methanol extracts and methanol fractions of $D$. tripetala seeds were shown to exert hypoglycemic and anti-hyperlipidemic effects in rats challenged with streptozotocin (Anioke et al., 2017). However, another study showed that the extract can trigger increases in gastric acid secretion in rats (Bright et al., 2017).

In 2017, D. tripetala powder was shown to be tolerated by rats when incorporated into their diet as a form of botanical pesticide (Nwosu et al., 2017). The aqueous and petroleum ether extracts were also found to elicit inhibitory effects on the activity of CYP3A enzymes in vitro (in rat liver and intestinal microsomes) and in vivo in rats (Nduka et al., 2017). In 2018, ethanolic extracts of D. tripetala fruits were shown to enhance the testosterone levels as well as the number and motility of sperm in rats (Obiandu and Green, 2018). 
More recently, we showed that the powder and aqueous and ethanolic extracts of $D$. tripetala fruits contain flavonoids, tannins, phenols, saponins, and alkaloids, and possess strong antioxidant properties (comparable to that of rutin) against 2,2-diphenyl-1-picrylhydrazyl, hydrogen peroxide, and ferric ions (Omage et al., 2018). Furthermore, we showed that the aqueous and ethanolic extracts of $D$. tripetala are not toxic to the liver, kidney, or heart of rats at doses of up to $5,000 \mathrm{mg} / \mathrm{kg}$ body weight (bw; acute exposure) and 1,000 mg/kg bw (28-day exposure). In other studies, the essential oils of $D$. tripetala seeds, particularly its $\beta$-phenylnitroethane component, exhibited memory-enhancing abilities (Oyemitan et al., 2019). The properties of $D$. tripetala have also been examined in humans. For example, the seeds have been found to reduce intraocular pressure of normotensive emmetropic humans (Timothy and Okere, 2008), and to elicit bronchiodilatory effects (Omigie et al., 2017).

Carbon tetrachloride $\left(\mathrm{CCl}_{4}\right)$ is a commonly used chemical for induction of hepatorenal injuries in laboratory animals; its mechanism of action is very well understood. $\mathrm{CCl}_{4}$ is metabolized by cytochrome $\mathrm{P} 450$ enzymes, leading to production of free radicals that trigger oxidative stress and damage cellular constituents, including lipids, proteins, and genetic material, eventually resulting in injury to organs including the liver (Weber et al., 2003) and kidneys (Sanzgiri et al., 1997). The toxicity of $\mathrm{CCl}_{4}$ is related to its dose and the duration of the exposure; higher doses and longer exposures tend to cause more serious and permanent effects (Weber et al., 2003).

In 2002, D. tripetala was shown to contain the alkaloid uvariopsine, which improves bile secretion and liver function (López-Martín et al., 2002). Our research group has also previously shown that $D$. tripetala extracts can prevent liver and kidney damage in vivo in rats subsequently exposed to a single administration of $\mathrm{CCl}_{4}$ (Iseghohi and Orhue, 2015; Iseghohi et al., 2017). In the present study, we tested the ability of ethanolic extracts of $D$. tripetala fruits to do the reverse, i.e., attenuate already existing liver and kidney lesions. These injuries were inflicted by repeated exposure to $\mathrm{CCl}_{4}$, in order to cause more severe damage than that induced by a single exposure to the toxin.

\section{MATERIALS AND METHODS}

\section{Plant materials}

Ripe $D$. tripetala fruits were purchased from a market in Benin City, Nigeria. The fruits were identified by a botanist in the Department of Plant Biology and Biotechnology, University of Benin as D. tripetala (family: Annonaceae), and a plant voucher number (UBHD360) was allocated. The fruits were diced, dried in the sun, and pul- verized into a powdery form. Then, $500 \mathrm{~g}$ of the powder was soaked in $4 \mathrm{~L}$ of ethanol for two days with regular agitation. The resulting filtrate (obtained with the aid of a cheese cloth) was freeze dried and reconstituted in distilled water for administration to animals.

\section{Phytochemical content, in vitro antioxidant properties, and toxicity study of the freeze-dried extract}

The phytochemical content, in vitro antioxidant properties and toxicity of the extract have been previously published (Omage et al., 2018).

\section{Animals}

Male albino Wistar rats of approximately 5 weeks of age and weighing 100 140 g were used in experiments. Rats were bred in wooden cages covered with barbed wire and allowed free access to feed (Growers' mash, Bendel Feed and Flour Mill Ltd., Ewu, Edo State, Nigeria) and water. The comfort of the rats was taken into consideration throughout the duration of the experiment. All animal experiments were carried out in accordance with the $\mathrm{NIH}$ guide for the care and use of laboratory animals (NIH publication No. 8023, revised 1978) and with permission from the Animal Ethics committee of the Faculty of Life Sciences, University of Benin, Nigeria (approval number LS16106). After acclimatizing for two weeks, rats were randomized into five groups of five. The experimental design is shown in Table 1.

Rats in the control group (group 1) were only administered feed and water. Rats in groups $2 \sim 5$ were administered $\mathrm{CCl}_{4}$ dissolved in olive oil $(1: 1 \mathrm{w} / \mathrm{v})$ at $3 \mathrm{~mL} / \mathrm{kg}$ bw twice a week for two weeks. Plant extract was dissolved in ethanol $(200 \mathrm{mg} / \mathrm{mL})$ and administered at doses of 250,500 , and $1,000 \mathrm{mg} / \mathrm{kg}$ bw to groups $3 \sim 5$, respectively, daily for seven days from day 8 of $\mathrm{CCl}_{4}$ administration. All experimental substances were administered orally using a gavage. On day 14 , rats were subjected to an overnight fast, and sacrificed on day 15 using chloroform anaesthesia. Blood (serum), liver, and kidneys were collected for biochemical assays and histopathology.

Table 1. Experimental design

\begin{tabular}{cc}
\hline Groups & Treatment \\
\hline 1 & Control \\
2 & $\mathrm{CCl}_{4}$ \\
3 & $\mathrm{CCl}_{4}+$ ETDT 250 \\
4 & $\mathrm{CCl}_{4}+$ ETDT 500 \\
5 & $\mathrm{CCl}_{4}+$ ETDT 1000
\end{tabular}

ETDT, ethanolic extract of Dennettia tripetala.

$D$. tripetala was administered in doses of 250,500 , and 1,000 $\mathrm{mg} / \mathrm{kg}$ bw $(\mathrm{n}=5)$. 


\section{Biochemical assays}

Rat serum was assayed for aspartate aminotransferase (AST), alanine aminotransferase (ALT), alkaline phosphatase (ALP), $\gamma$-glutamyltransferase (GGT), total cholesterol, triglyceride, total protein, albumin, globulin, urea, and creatinine. Livers and kidneys were assayed for superoxide dismutase (SOD), catalase, and malondialdehyde (MDA). All but four assays were conducted using kits from Randox Laboratories (Crumlin, UK), following the manufacturer's protocol. SOD, catalase, and MDA assays were conducted using reagents purchased from Pyrex-Ig Science/laboratory (Benin City, Nigeria), following methods described by Misra and Fridovich (1972), Góth (1991), and Buege and Aust (1978) for SOD, catalase, and MDA assays, respectively. ALP was assessed using kits from Teco Diagnostics (Anaheim, CA, USA), following manufacturer's instructions.

\section{Histopathology}

Portions of the liver and kidneys were fixed in $10 \%$ neutral buffered formalin for histopathological analysis. A Leica TP1020 automatic tissue processor (Leica Biosystems, Wetzlar, Germany) was used to process the tissues, which were stained with hematoxylin and eosin and viewed under a light microscope using both $10 \times$ and $40 \times$ magnification.

\section{Statistics}

Data were analyzed using one-way ANOVA and Tukey's post-hoc test and presented as mean \pm standard error of the mean (SEM). GraphPad Prism version 7 software (GraphPad Software, San Diego, CA, USA) was used for data analysis.

\section{RESULTS}

\section{Effect on liver marker enzymes in serum}

$\mathrm{CCl}_{4}$ treatment induced significant increases in the activities of the liver marker enzymes AST and ALT in serum, and a non-significant elevation of ALP (Table 2). The ethanolic extract of $D$. tripetala fruits helped alleviate damage induced by $\mathrm{CCl}_{4}$, by lowering the activities of ALT, AST, and ALP in serum of the rats administered $\mathrm{CCl}_{4}$ and extracts vs. rats administered $\mathrm{CCl}_{4}$ alone.

\section{Effect on lipid homeostasis}

Furthermore, $\mathrm{CCl}_{4}$ significantly elevated serum total cholesterol and low-density lipoprotein (LDL)-cholesterol and significantly reduced serum high-density lipoprotein (HDL)-cholesterol and triacylglycerol (TAG) (Table 3). The ethanolic extract of $D$. tripetala showed low potential for alleviating the distortions in lipid concentrations that were altered by $\mathrm{CCl}_{4}$. In the liver, $\mathrm{CCl}_{4}$ elevated the concentration of cholesterol and TAGs (Table 4), and caused steatosis (fatty accumulation) in liver cells (Fig. 1 and Fig. 2). D. tripetala extracts lowered the concentration of these lipids in the liver (Table 4, Fig. 1, and Fig. 2).

Table 2. Effect of Dennettia tripetala on serum activity of liver marker enzymes in rats administered $\mathrm{CCl}_{4}$

\begin{tabular}{llcc}
\hline \multicolumn{1}{c}{ Groups } & \multicolumn{1}{c}{ AST } & ALT & ALP \\
\hline Control & $242.10 \pm 6.55^{\mathrm{a}}$ & $52.50 \pm 4.79^{\mathrm{a}}$ & $39.15 \pm 5.88^{\mathrm{a}}$ \\
$\mathrm{CCl}{ }_{4}$ & $809.00 \pm 15.6^{\mathrm{c}}$ & $486.70 \pm 6.67^{\mathrm{b}}$ & $45.70 \pm 1.59^{\mathrm{a}}$ \\
ETDT 250+CCl & $493.50 \pm 19.64^{\mathrm{b}}$ & $460.00 \pm 48.99^{\mathrm{b}}$ & $58.06 \pm 5.11^{\mathrm{b}}$ \\
ETDT 500+CCl & $465.30 \pm 6.36^{\mathrm{b}}$ & $336.70 \pm 38.44^{\mathrm{b}}$ & $44.81 \pm 3.15^{\mathrm{a}}$ \\
ETDT 1000+CCl & $520.00 \pm 1.16^{\mathrm{b}}$ & $362.50 \pm 34.73^{\mathrm{b}}$ & $43.63 \pm 2.72^{\mathrm{a}}$ \\
\hline
\end{tabular}

The values presented are the mean \pm SEM $(n=5)$.

Values with different letters $(a-c)$ within the same column are significantly different at $P<0.05$.

ETDT, ethanolic extract of $D$. tripetala; AST, aspartate aminotransferase; ALT, alanine aminotransferase; ALP, alkaline phosphatase. $D$. tripetala was administered in doses of 250,500 , and $1,000 \mathrm{mg} / \mathrm{kg} \mathrm{bw}$.

Table 3. Effect of Dennettia tripetala on serum lipid concentration in rats administered $\mathrm{CCl}_{4}$ (unit: $\mathrm{mg} / \mathrm{dL}$ )

\begin{tabular}{lcccc}
\hline \multicolumn{1}{c}{ Groups } & Total cholesterol & HDL-cholesterol & LDL-cholesterol & TAG \\
\hline Control & $38.28 \pm 1.93^{\mathrm{a}}$ & $25.45 \pm 2.20^{\mathrm{b}}$ & $13.75 \pm 0.95^{\mathrm{a}}$ & $127.40 \pm 25.10^{\mathrm{c}}$ \\
$\mathrm{CCl}_{4}$ & $47.85 \pm 1.08^{\mathrm{b}}$ & $7.24 \pm 0.64^{\mathrm{a}}$ & $41.07 \pm 0.94^{\mathrm{b}}$ & $84.30 \pm 4.43^{\mathrm{b}}$ \\
ETDT 250+CCl 4 & $47.09 \pm 0.61^{\mathrm{b}}$ & $28.57 \pm 0.24^{\mathrm{b}}$ & $23.08 \pm 3.12^{\mathrm{a}}$ & $46.62 \pm 4.91^{\mathrm{a}}$ \\
ETDT 500+CCl & $47.40 \pm 2.10^{\mathrm{b}}$ & $24.89 \pm 2.82^{\mathrm{b}}$ & $32.33 \pm 3.65^{\mathrm{b}}$ & $72.00 \pm 6.79^{\mathrm{b}}$ \\
ETDT 1000+CCl & $42.84 \pm 1.39^{\mathrm{ab}}$ & $9.57 \pm 0.97^{\mathrm{a}}$ & $38.30 \pm 0.58^{\mathrm{b}}$ & $49.23 \pm 2.22^{\mathrm{a}}$ \\
\hline
\end{tabular}

The values presented are the mean $\pm \operatorname{SEM}(n=5)$.

Values with different letters $(a-c)$ within the same column are significantly different at $P<0.05$.

ETDT, ethanolic extract of $D$. tripetala; HDL, high-density lipoprotein; LDL, low-density lipoprotein; TAG, triacylglycerols.

$D$. tripetala was administered in doses of 250,500 , and $1,000 \mathrm{mg} / \mathrm{kg} \mathrm{bw}$. 
Table 4. Effect of Dennettia tripetala administration on liver lipid concentration in rats administered $\mathrm{CCl}_{4}$ (unit: $\mathrm{mg} / \mathrm{dL}$ )

\begin{tabular}{lcc}
\hline \multicolumn{1}{c}{ Groups } & Total cholesterol & TAG \\
\hline Control & $41.68 \pm 0.49^{\mathrm{a}}$ & $16.88 \pm 2.11^{\mathrm{a}}$ \\
$\mathrm{CCl}_{4}$ & $51.44 \pm 7.59^{\mathrm{b}}$ & $28.84 \pm 6.01^{\mathrm{ab}}$ \\
ETDT $250+\mathrm{CCl}_{4}$ & $44.06 \pm 0.97^{\mathrm{a}}$ & $7.74 \pm 0.70^{\mathrm{a}}$ \\
ETDT $500+\mathrm{CCl}_{4}$ & $44.46 \pm 0.23^{\mathrm{a}}$ & $11.96 \pm 0.70^{\mathrm{a}}$ \\
ETDT $1000+\mathrm{CCl}_{4}$ & $46.44 \pm 0.33^{\mathrm{ab}}$ & $16.35 \pm 5.05^{\mathrm{a}}$ \\
\hline
\end{tabular}

The values presented are the mean $\pm \operatorname{SEM}(n=5)$.

Values with different letters $(a, b)$ within the same column are significantly different at $P<0.05$.

ETDT, ethanolic extract of $D$. tripetala; TAG, triacylglycerols. $D$. tripetala was administered in doses of 250,500 , and 1,000 $\mathrm{mg} / \mathrm{kg}$ bw.

\section{Effect on serum protein profile}

$\mathrm{CCl}_{4}$ significantly elevated the total protein and globulin concentrations in serum and significantly reduced serum albumin levels and the albumin : globulin ratio (Table 5). Therefore, we concluded that $D$. tripetala ethanolic extract shows potential for restoring normal concentrations of serum proteins.

\section{Effect on recruitment of immune cells in the liver}

Histopathology images revealed that $\mathrm{CCl}_{4}$ caused immune cells to be recruited to the sites of damage in the liver (Fig. 1 and Fig. 2).
Effect on antioxidant enzyme activities in liver and kidneys $\mathrm{CCl}_{4}$ induced a reduction in the activities of the antioxidant enzymes SOD and catalase in both the liver and the kidneys (Table 6 and Table 7). In addition, $\mathrm{CCl}_{4}$ significantly elevated the concentration of the lipid peroxidation product malondialdehyde in both the liver and kidneys. Interestingly, $D$. tripetala ethanolic extract significantly elevated the activities of the antioxidant enzymes and reduced malondialdehyde levels in the liver and kidneys of rats administered $\mathrm{CCl}_{4}$ and the extract compared with rats administered $\mathrm{CCl}_{4}$ alone.

\section{Effect on serum urea and creatinine concentrations}

$\mathrm{CCl}_{4}$ elevated the concentration of urea and creatinine in serum (Table 8). This observation was supported by histopathology results (Fig. 3 and Fig. 4) showing that $\mathrm{CCl}_{4}$ severely altered the structure of the kidneys. In addition, D. tripetala ethanolic extract reduced urea and creatinine concentrations in the serum of rats administered $\mathrm{CCl}_{4}$ and the extracts compared with rats administered $\mathrm{CCl}_{4}$ alone; the observation further supported by histopathology results (Fig. 3 and Fig. 4).

\section{DISCUSSION}

\section{Effect on liver marker enzymes in serum}

ALT and AST are normally localized in the cells of the
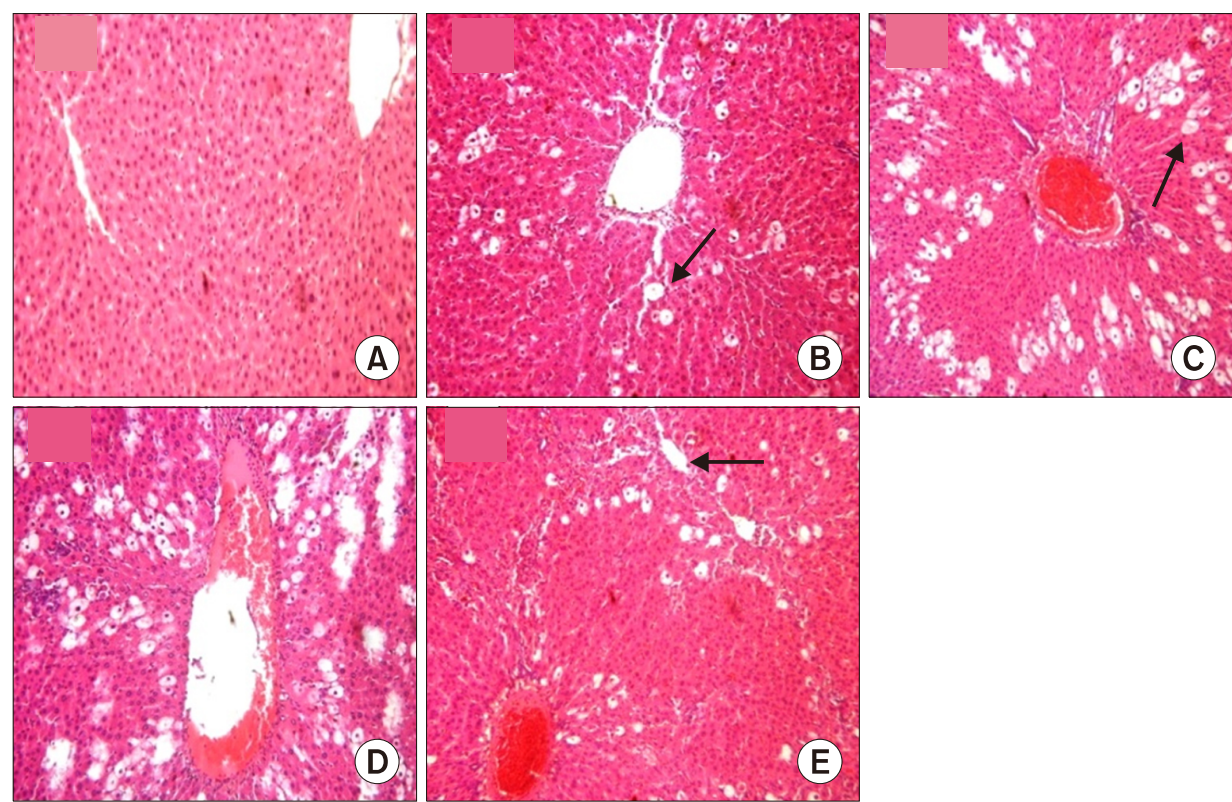

Fig. 1. Photomicrographs of liver sections from (A) control rats showing normal liver histology: clear centrioles with well fenestrated sinusoidal space and distinct hepatocytes; (B) rats treated with $250 \mathrm{mg} / \mathrm{kg}$ bw ETDT and $\mathrm{CCl}_{4}$, showing very mild fatty changes with clear centrioles; (C) rats treated with $500 \mathrm{mg} / \mathrm{kg}$ bw ETDT and $\mathrm{CCl}_{4}$, showing fatty changes and little hydropic degeneration of the hepatocytes, with centrioles appearing congested surrounded by neutrophilic infiltrates; (D) rats treated with 1,000 mg/kg bw ETDT and $\mathrm{CCl}_{4}$, showing fatty changes with partially clear centrioles surrounded by visible multifocal neutrophilic infiltrates; (E) rats treated with $\mathrm{CCl}_{4}$ only, showing fatty changes (macrovsicular steatosis) and hydropic degeneration of the hepatocytes with multifocal distortion in liver histology, congestion of the central vein, with neutrophilic infiltrates. The liver sections were stained with hematoxylin and eosin and observed with a 10x objective. ETDT, D. tripetala ethanolic extract. 

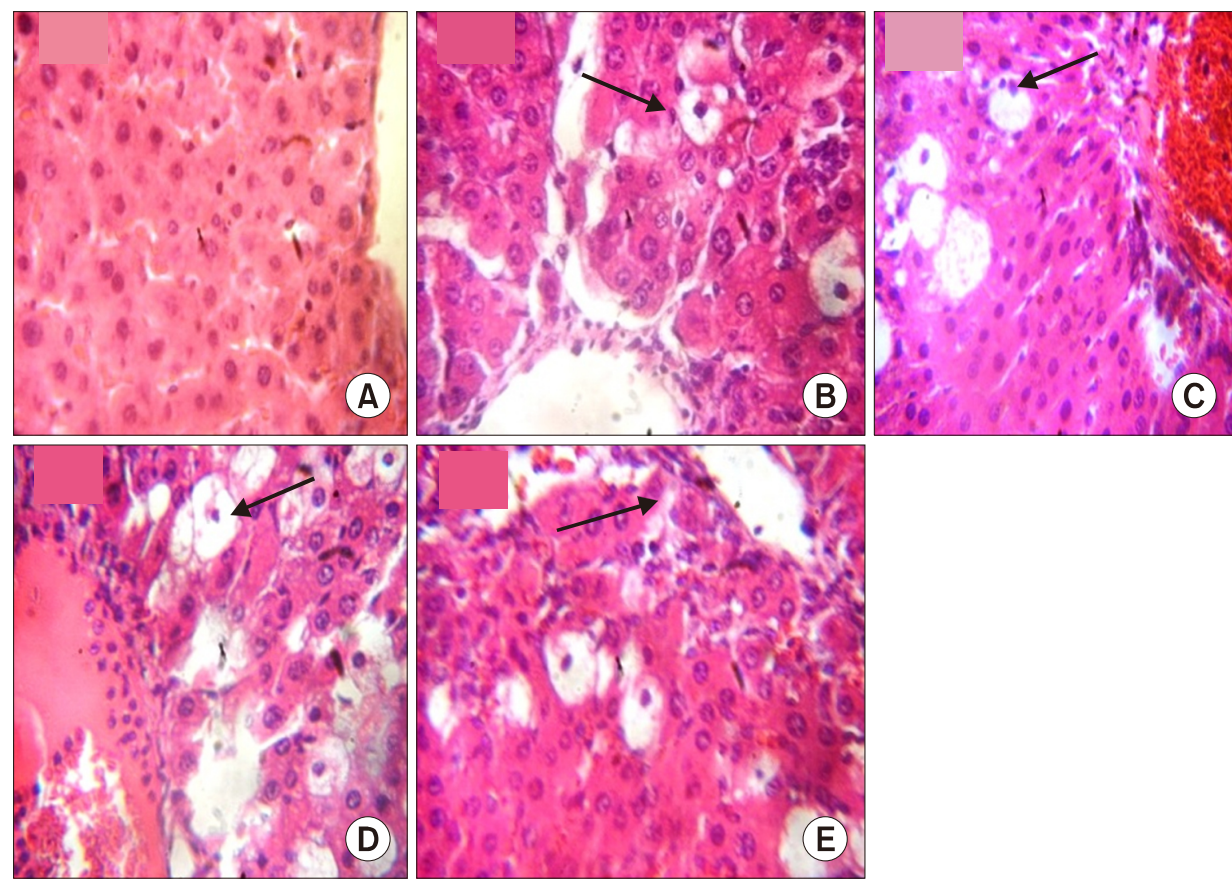

Fig. 2. Photomicrographs of liver sections from (A) control rats showing normal liver histology: clear centrioles with well fenestrated sinusoidal space and distinct hepatocytes with well differentiated nucleus; (B) rats treated with $250 \mathrm{mg} / \mathrm{kg}$ bw ETDT and CCl showing very mild fatty changes although with clear centrioles; (C) rats treated with $500 \mathrm{mg} / \mathrm{kg}$ bw ETDT and $\mathrm{CCl}_{4}$, showing fatty changes and little hydropic degeneration of the hepatocytes, with centriole appearing congested surrounded by neutrophilic infiltrates; (D) rats treated with $1,000 \mathrm{mg} / \mathrm{kg}$ bw ETDT and $\mathrm{CCl}_{4}$, showing fatty changes with partially clear centrioles surrounded by visible multifocal neutrophilic infiltrates; (E) rats treated with $\mathrm{CCl}_{4}$ only showing fatty changes (macrovsicular steatosis) and hydropic degeneration of the hepatocytes with multifocal distortion in liver histology, congestion of the central vein with neutrophilic infiltrates. The liver sections were stained with hematoxylin and eosin and observed with a 40× objective. ETDT, D. tripetala ethanolic extract.

Table 5. Effect of Dennettia tripetala on serum protein concentration in rats administered $\mathrm{CCl}_{4}$

\begin{tabular}{lcccc}
\hline \multicolumn{1}{c}{ Groups } & $\begin{array}{c}\text { Total protein } \\
(\mathrm{g} / \mathrm{dL})\end{array}$ & $\begin{array}{c}\text { Albumin } \\
(\mathrm{g} / \mathrm{dL})\end{array}$ & $\begin{array}{c}\text { Globulin } \\
(\mathrm{g} / \mathrm{dL})\end{array}$ & Albumin : globulin ratio \\
\hline Control & $5.94 \pm 0.18^{\mathrm{a}}$ & $3.24 \pm 0.04^{\mathrm{b}}$ & $2.68 \pm 0.09^{\mathrm{a}}$ & $1.13 \pm 0.04^{\mathrm{c}}$ \\
$\mathrm{CCl}_{4}$ & $21.04 \pm 1.45^{\mathrm{c}}$ & $2.96 \pm 0.03^{\mathrm{a}}$ & $14.05 \pm 1.67^{\mathrm{b}}$ & $0.18 \pm 0.02^{\mathrm{a}}$ \\
ETDT 250+CCl $\mathrm{Cl}_{4}$ & $13.11 \pm 0.95^{\mathrm{b}}$ & $2.71 \pm 0.05^{\mathrm{a}}$ & $10.42 \pm 0.91^{\mathrm{b}}$ & $0.26 \pm 0.02^{\mathrm{a}}$ \\
ETDT 500+CCl 4 & $8.69 \pm 1.05^{\mathrm{a}}$ & $3.38 \pm 0.02^{\mathrm{b}}$ & $6.12 \pm 1.34^{\mathrm{a}}$ & $0.31 \pm 0.10^{\mathrm{a}}$ \\
ETDT 1000+CCl & $9.35 \pm 0.25^{\mathrm{a}}$ & $2.82 \pm 0.07^{\mathrm{a}}$ & $6.06 \pm 0.45^{\mathrm{a}}$ & $0.46 \pm 0.05^{\mathrm{b}}$ \\
\hline
\end{tabular}

The values presented are the mean $\pm \operatorname{SEM}(n=5)$.

Values with different letters $(\mathrm{a}-\mathrm{c})$ within the same column are significantly different at $P<0.05$.

ETDT, ethanolic extract of $D$. tripetala.

D. tripetala was administered in doses of 250,500 , and $1,000 \mathrm{mg} / \mathrm{kg} \mathrm{bw}$.

Table 6. Effect of Dennettia tripetala on liver antioxidant enzyme activity and lipid peroxidation status in rats administered $\mathrm{CCl}_{4}$

(unit: units/g wet tissue)

\begin{tabular}{lccc}
\hline \multicolumn{1}{c}{ Groups } & SOD & Catalase & MDA \\
\hline Control & $1,225 \pm 3^{\mathrm{c}}$ & $4,683 \pm 11^{\mathrm{c}}$ & $0.08 \pm 0.01^{\mathrm{a}}$ \\
$\mathrm{CCl}$ & $744.0 \pm 2^{\mathrm{a}}$ & $4,326 \pm 51^{\mathrm{a}}$ & $0.17 \pm 0.01^{\mathrm{c}}$ \\
ETDT 250+CCl & $891.7 \pm 36^{\mathrm{b}}$ & $4,386 \pm 31^{\mathrm{a}}$ & $0.09 \pm 0.01^{\mathrm{a}}$ \\
ETDT 500+CCl 4 & $1,500 \pm 25^{\mathrm{d}}$ & $4,518 \pm 8^{\mathrm{b}}$ & $0.10 \pm 0.01^{\mathrm{ab}}$ \\
ETDT 1000+CCl & $1,125 \pm 52^{\mathrm{c}}$ & $4,656 \pm 45^{\mathrm{c}}$ & $0.09 \pm 0.01^{\mathrm{a}}$ \\
\hline
\end{tabular}

The values presented are the mean $\pm \operatorname{SEM}(n=5)$.

Values with different letters (a-d) within the same column are significantly different at $P<0.05$.

ETDT, ethanolic extract of $D$. tripetala; SOD, superoxide dismutase; MDA, malondialdehyde.

$D$. tripetala was administered in doses of 250,500 , and $1,000 \mathrm{mg} / \mathrm{kg} \mathrm{bw}$. 
Table 7. Effect of Dennettia tripetala on kidney antioxidant enzyme activity and lipid peroxidation status in rats administered $\mathrm{CCl}_{4}$

\begin{tabular}{lccc}
\hline \multicolumn{1}{c}{ Groups } & $\begin{array}{c}\text { SOD } \\
\left.\text { [units/g wet tissue }\left(\times 10^{-2}\right)\right]\end{array}$ & $\begin{array}{c}\text { Catalase } \\
\text { (units/g wet tissue) }\end{array}$ & $\begin{array}{c}\text { MDA } \\
\text { (units/g wet tissue) }\end{array}$ \\
\hline Control & $873 \pm 28^{\mathrm{a}}$ & $5,076 \pm 294^{\mathrm{b}}$ & $0.20 \pm 0.01^{\mathrm{a}}$ \\
$\mathrm{CCl}{ }_{4}$ & $644 \pm 28^{\mathrm{a}}$ & $3,984 \pm 18^{\mathrm{a}}$ & $0.25 \pm 0.01^{\mathrm{b}}$ \\
ETDT 250+CCl & $1,130 \pm 346^{\mathrm{a}}$ & $4,749 \pm 11^{\mathrm{b}}$ & $0.21 \pm 0.01^{\mathrm{a}}$ \\
ETDT 500+CCl & $1,027 \pm 208^{\mathrm{a}}$ & $4,815 \pm 26^{\mathrm{b}}$ & $0.19 \pm 0.01^{\mathrm{a}}$ \\
ETDT 1000+CCl & $1,030 \pm 79^{\mathrm{a}}$ & $4,827 \pm 7^{\mathrm{b}}$ & $0.23 \pm 0.01^{\mathrm{ab}}$ \\
\hline
\end{tabular}

The values presented are the mean $\pm \operatorname{SEM}(n=5)$.

Values with different letters $(a, b)$ within the same column are significantly different at $P<0.05$.

ETDT, ethanolic extract of $D$. tripetala; SOD, superoxide dismutase; MDA, malondialdehyde.

$D$. tripetala was administered in doses of 250,500 , and $1,000 \mathrm{mg} / \mathrm{kg} \mathrm{bw}$.

Table 8. Effect of Dennettia tripetala on urea and creatinine concentrations in rats administered $\mathrm{CCl}_{4}$ (unit: $\mathrm{mg} / \mathrm{dL}$ )

\begin{tabular}{lcc}
\hline \multicolumn{1}{c}{ Groups } & Urea & Creatinine \\
\hline Control & $6.43 \pm 0.83^{\mathrm{a}}$ & $1.54 \pm 0.01^{\mathrm{a}}$ \\
$\mathrm{CCl}_{4}$ & $10.73 \pm 0.04^{\mathrm{b}}$ & $2.15 \pm 0.02^{\mathrm{b}}$ \\
ETDT $250+\mathrm{CCl}_{4}$ & $8.31 \pm 0.63^{\mathrm{b}}$ & $1.36 \pm 0.03^{\mathrm{a}}$ \\
ETDT $500+\mathrm{CCl}_{4}$ & $7.53 \pm 0.72^{\mathrm{ab}}$ & $1.48 \pm 0.14^{\mathrm{a}}$ \\
ETDT $1000+\mathrm{CCl}_{4}$ & $7.37 \pm 0.87^{\mathrm{ab}}$ & $1.36 \pm 0.07^{\mathrm{a}}$ \\
\hline
\end{tabular}

The values presented are the mean $\pm \operatorname{SEM}(n=5)$.

Values with different letters $(a, b)$ within the same column are significantly different at $P<0.05$.

ETDT, ethanolic extract of $D$. tripetala.

$D$. tripetala was administered in doses of 250,500 , and 1,000 $\mathrm{mg} / \mathrm{kg} \mathrm{bw}$.

liver, but can drain into the blood and cause noticeable elevations following damage to the membranes of hepatocytes, as is the case with the metabolites of $\mathrm{CCl}_{4}$ (Singh et al., 2011). This readily occurs in the liver, which contains a high amount of cytochrome P450 enzymes responsible for metabolizing drugs and toxins. In the present study, the ethanolic extract of $D$. tripetala fruits alleviated damage induced by $\mathrm{CCl}_{4}$, observed by lower activities of ALT, AST, and ALP in the serum of the rats administered extracts and $\mathrm{CCl}_{4}$ compared with $\mathrm{CCl}_{4}$ alone. $D$. tripetala contains flavonoids and phenols that elicit antioxidant effects. In addition, $D$. tripetala elicits in vitro antioxidant effects (Omage et al., 2018). Therefore, D. tripetala may have alleviated the damage by combating lipid peroxidation caused by trichloromethyl radicals produced during $\mathrm{CCl}_{4}$ metabolism in the liver, thus protecting hepatocyte membranes from distortion that could cause spillage of enzymes into the blood.

\section{Effect on lipid homeostasis}

Dyslipidemia is caused by increases in total cholesterol and LDL-cholesterol and decreases HDL-cholesterol in serum, and is a risk factor for atherosclerosis and other diseases of the heart and blood vessels (Mahdy Ali et al., 2012). Certain extents of damage to the liver have been shown to alter its ability to synthesize, package, and se- crete lipids into the blood (Fromenty and Pessayre, 1995; Boll et al., 2001; Khalaf et al., 2009; Al-Yahya et al., 2013; Hamed et al., 2016). Therefore, it was unsurprising that recurrent challenges with $\mathrm{CCl}_{4}$ induced dyslipidemia. However, D. tripetala ethanolic extract showed low potential to alleviate the distortions in lipid concentrations altered by $\mathrm{CCl}_{4}$. The mechanism of action of $D$. tripetala extract may include restoration of the liver's ability to metabolize these lipids. Our findings also indicated that $\mathrm{CCl}_{4}$ elevates the concentration of cholesterol and TAGs in the liver, which supports the hypothesis that $\mathrm{CCl}_{4}$ may alter the ability of the liver to metabolize lipids. In this case, $\mathrm{CCl}_{4}$ most likely increased synthesis of cholesterol in the liver, which may have elevated the concentration of total cholesterol in the serum. On the other hand, since TAGs accumulated in the liver, secretion of TAGs by the liver may have been impaired, leading to a noticeable drop in serum TAG levels. This result is supported by histopathology images of the liver (Fig. 1 and Fig. 2) that show steatosis (fatty accumulation) in the liver cells. D. tripetala extracts lowered the concentration of these lipids in the liver (Table 4, Fig. 1, and Fig. 2).

\section{Effect on serum protein profiles}

The elevated total protein in the serum may comprise that which leaked out of the injured liver. The decrease in albumin may indicate that the liver had difficulty synthesizing normal amounts of this protein following injury induced by $\mathrm{CCl}_{4}$. The ethanolic extract of $D$. tripetala showed potential in restoring the concentrations of serum proteins to normal. It is unsurprising that the extract reduced the concentrations of total proteins since the extract reduced the amount of enzymes that leaked out of the liver in the first place. In the case of albumin, the extract may have restored (to some extent) the synthetic capacity of the liver, leading to concentrations similar to those of the control group. In general, the $D$. tripetala extracts altered the albumin: globulin ratio towards that recorded in the control group. 

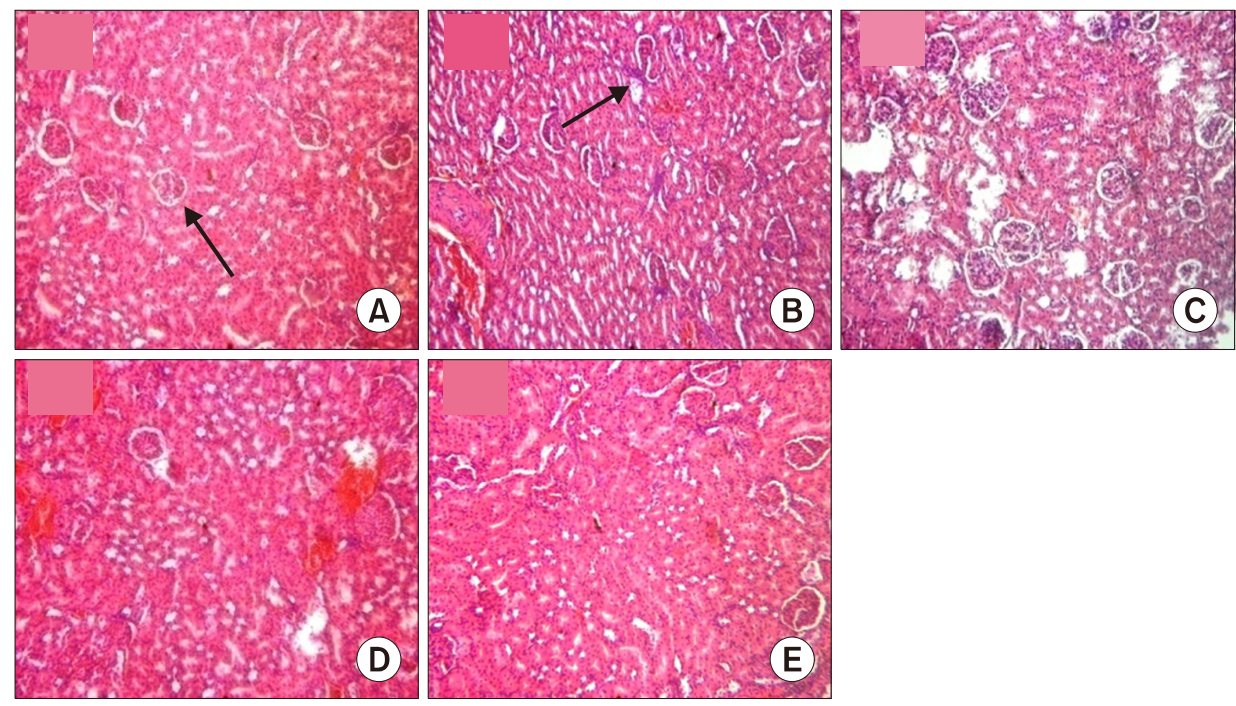

Fig. 3. Photomicrographs of kidney sections from (A) control rats showing normal histological features. The section indicates a detailed cortical parenchyma and the renal corpuscles appear as dense rounded structures; (B) rats treated with $250 \mathrm{mg} / \mathrm{kg}$ bw ETDT and $\mathrm{CCl}_{4}$, showing a varying degree of distortion and disruption in microanatomy of the renal cortex (atrophy), when compared to the control although with prominent renal corpuscles; (C) rats treated with $500 \mathrm{mg} / \mathrm{kg}$ bw ETDT and $\mathrm{CCl}_{4}$, showing some degree of recovery in microanatomy of the renal cortex, including queried edema, when compared to the control with some atrophied renal corpuscles; (D) rats treated with $1,000 \mathrm{mg} / \mathrm{kg}$ bw ETDT and $\mathrm{CCl}_{4}$, showing some degree of distortion in microanatomy of the renal cortex, including queried edema, when compared to the control; $(\mathrm{E})$ rats treated with $\mathrm{CCl}_{4}$ only, showing severe distortion and disruption in microanatomy of the renal cortex, including queried edema. The kidney sections were stained with hematoxylin and eosin and observed with a $10 \times$ objective. ETDT, D. tripetala ethanolic extract.
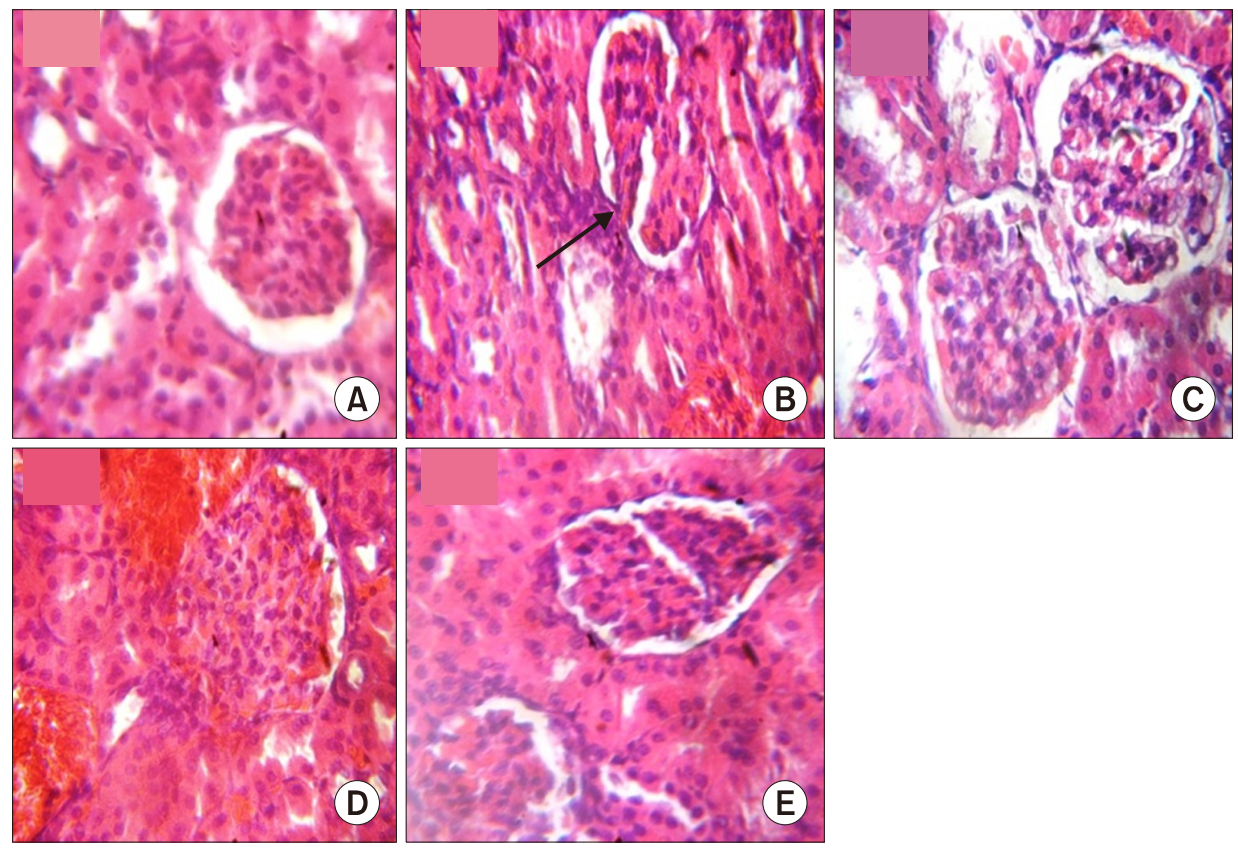

Fig. 4. Photomicrographs of kidney sections from (A) control rats showing normal histological features. The section indicates a detailed cortical parenchyma and the renal corpuscles appear as dense rounded structures; (B) rats treated with $250 \mathrm{mg} / \mathrm{kg}$ bw ETDT and $\mathrm{CCl}_{4}$ showing some degree of distortion and disruption in microanatomy of the renal cortex (atrophy), when compared to the control, although with prominent renal corpuscles; (C) rats treated with $500 \mathrm{mg} / \mathrm{kg}$ bw ETDT and $\mathrm{CCl}_{4}$ showing some varying degree of recovery in microanatomy of the renal cortex, including queried edema, when compared to the control with some atrophied renal corpuscles; (D) rats treated with $1,000 \mathrm{mg} / \mathrm{kg}$ bw ETDT and $\mathrm{CCl}_{4}$ showing some varying degree of distortion in microanatomy of the renal cortex, including queried edema, when compared to the control; (E) rats treated with $\mathrm{CCl}_{4}$ only showing severe distortion and disruption in microanatomy of the renal cortex, including queried edema. The kidney sections were stained with hematoxylin and eosin and observed with a 40x objective. ETDT, D. tripetala ethanolic extract.

\section{Effect on recruitment of immune cells in the liver}

Histopathology images revealed that $\mathrm{CCl}_{4}$ caused immune cells to be recruited to the sites of damage in the liver
(Fig. 1 and Fig. 2). This is unsurprising since $\mathrm{CCl}_{4}$ is a foreign substance and is capable of evoking an immune response in vivo by inducing Kupffer cells to release cyto- 
kines such as tumor necrosis factor- $\alpha$, transforming growth factor- $\beta$, nitric oxide, and various interleukins (Weber et al., 2003). D. tripetala extract did not noticeably alter infiltration of immune cells in the liver. Therefore, under the conditions of this experiment, $D$. tripetala extract did not majorly influence the ability of the local immune system of the liver to deal with the toxicant $\mathrm{CCl}_{4}$.

\section{Effect on antioxidant enzyme activities in livers and kidneys}

Metabolism of $\mathrm{CCl}_{4}$ caused oxidative stress in the liver and kidneys by decreasing SOD and catalase activities and increasing the concentration of the lipid peroxidation product malondialdehyde. $\mathrm{CCl}_{4}$ radical formed from the breakdown of $\mathrm{CCl}_{4}$ can form DNA adducts as well as protein adducts, which may lead to impairment of the function of certain genes and proteins (Weber et al., 2003). In this study, it is possible that the metabolites of $\mathrm{CCl}_{4}$ reduced antioxidant enzymes by randomly inhibiting their formation and function at both the genetic and protein levels. Our results show that in the context of this experiment, D. tripetala used an antioxidant mechanism to alleviate damage to organs caused by $\mathrm{CCl}_{4}$.

\section{Effect on serum urea and creatinine concentrations}

Urea and creatinine are waste products of metabolism that are normally filtered by the kidneys into the urine. However, alterations to the structure of the kidneys may affect its ability to efficiently filter these waste products, leading to their elevation in the blood (Ravnskov, 2005). In this study, $\mathrm{CCl}_{4}$ increased the concentrations of urea and creatinine in serum, while $D$. tripetala extract restored the concentrations to normal. These results in combination with the histopathology images (Fig. 3 and Fig. 4) suggest that $D$. tripetala extracts can largely restore the architecture of the kidneys following treatment with $\mathrm{CCl}_{4}$.

In conclusion, our study provides evidence that the ethanolic extract of $D$. tripetala fruits alleviate damage to the organs of rats caused by oxidative stress resulting from repeated exposures to $\mathrm{CCl}_{4}$. Going forward, it may be possible to extract or semi-synthesize drugs for the treatment of liver and kidney diseases from $D$. tripetala.

\section{AUTHOR DISCLOSURE STATEMENT}

The authors declare no conflict of interest.

\section{AUTHOR CONTRIBUTIONS}

SOO and NEJO designed the study. SOO and KO carried out the experiments. SOO analyzed the data and wrote the manuscript. All authors approved the final copy of the manuscript.

\section{REFERENCES}

Al-Yahya M, Mothana R, Al-Said M, Al-Dosari M, Al-Musayeib N, Al-Sohaibani $\mathrm{M}$, et al. Attenuation of $\mathrm{CCl}_{4}$-induced oxidative stress and hepatonephrotoxicity by Saudi Sidr honey in rats. Evid Based Complement Alternat Med. 2013. 2013:569037. https://doi.org/10.1155/2013/569037

Anioke I, Okwuosa C, Uchendu I, Chijioke O, Dozie-Nwakile O, Ikegwuonu I, et al. Investigation into hypoglycemic, antihyperlipidemic, and renoprotective potentials of Dennettia tripetala (pepper fruit) seed in a rat model of diabetes. Biomed Res Int. 2017. 2017:6923629. https://doi.org/10.1155/2017/6923629

Boll M, Weber LW, Becker E, Stampfl A. Hepatocyte damage induced by carbon tetrachloride: inhibited lipoprotein secretion and changed lipoprotein composition. Z Naturforsch C J Biosci. 2001. 56:283-290.

Bright E, Mfem C, Ugumanim A, Ukpong M. The effect of ethanol extract of Dennettia tripetala (pepper fruit) on gastric acid secretion in Wistar rats. Res Rev J Med Health Sci. 2017. 6:21-26.

Buege JA, Aust SD. Microsomal lipid peroxidation. Methods Enzymol. 1978. 52:302-310.

Fromenty B, Pessayre D. Inhibition of mitochondrial beta-oxidation as a mechanism of hepatotoxicity. Pharmacol Ther. 1995. 67:101-154.

Góth L. A simple method for determination of serum catalase activity and revision of reference range. Clin Chim Acta. 1991. 196:143-151.

Hamed SS, Al-Yhya NA, El-Khadragy MF, Al-Olayan EM, Alajmi RA, Hassan ZK, et al. The protective properties of the strawberry (Fragaria ananassa) against carbon tetrachloride-induced hepatotoxicity in rats mediated by anti-apoptotic and upregulation of antioxidant genes expression effects. Front Physiol. 2016. 7:325. https://doi.org/10.3389/fphys.2016.00325

Ihemeje A, Ojinnaka MC, Obi KC, Ekwe CC. Biochemical evaluation of pepper fruit (Dennettia tripetala) and its use as substitute for ginger in zobo drink production. Acad Res Int. 2013. 4:513521.

Iseghohi SO, Orhue EJN. Aqueous extract of Dennettia tripetala (pepperfruit) protects the liver and kidney against carbon tetrachloride-induced damage in rats. NISEB J. 2015. 15:106-111.

Iseghohi SO, Orhue NEJ, Omage K. Pre-exposure to Dennettia tripetala ethanolic fruit extract prevents biochemical alterations in rats subsequently exposed to a single dose of carbon tetrachloride. Int J Pharmacol Phytochem Ethnomed. 2017. 6:8-16.

Iseghohi SO. A review of the uses and medicinal properties of Dennettia tripetala (pepperfruit). Med Sci. 2015. 3:104-111.

Khalaf AAA, Mekawy MEM, Moawad MS, Ahmed AM. Comparative study on the protective effect of some antioxidants against $\mathrm{CCl}_{4}$ hepatotoxicity in rats. Egy J Nat Toxins. 2009. 6:59-82.

López-Martín J, Anam EM, Boira H, Sanz MJ, Blázquez MA. Chromone and phenanthrene alkaloids from Dennettia tripetala. Chem Pharm Bull. 2002. 50:1613-1615.

Mahdy Ali K, Wonnerth A, Huber K, Wojta J. Cardiovascular disease risk reduction by raising HDL cholesterol - current therapies and future opportunities. Br J Pharmacol. 2012. 167:11771194.

Misra HP, Fridovich I. The role of superoxide anion in the autoxidation of epinephrine and a simple assay for superoxide dismutase. J Biol Chem. 1972. 247:3170-3175.

Nduka SO, Okonta MJ, Ajaghaku DL, Ukwe CV. In vitro and in vivo cytochrome P450 3A enzyme inhibition by Aframomum melegueta and Denniettia tripetala extracts. Asian Pac J Trop Med. 
2017. 10:576-581.

Nwosu LC, Adedire CO, Ogunwolu EO, Ashamo MO. Toxicological and histopathological effects of Dennettia tripetala seed used as grain protectant, food, and medicine. Food Qual Saf. 2017. 1:211-220.

Obiandu C, Green K. Evaluation of the ethanolic extract of the fruit of Dennettia tripetala on fertility indices of male Wistar rats. Int J Sci Res. 2018. 7:1524-1528.

Okoh SO, Iweriegbor BC, Okoh OO, Nwodo UU, I Okoh A. Bactericidal and antioxidant properties of essential oils from the fruits Dennettia tripetala G. Baker. BMC Complement Altern Med. 2016. 16:486. https://doi.org/10.1186/s12906-016$1459-4$

Okolie NP, Falodun A, Davids O. Evaluation of the antioxidant activity of root extract of pepper fruit (Dennetia tripetala), and it's potential for the inhibition of lipid peroxidation. Afr J Tradit Complement Altern Med. 2014. 11:221-227.

Omage SO, Orhue NEJ, Omage K. Evaluation of the phytochemical content, in vitro antioxidant capacity, biochemical and histological effects of Dennettia tripetala fruits in healthy rats. Food Sci Nutr. 2018. 7:65-75.

Omigie MI, Agoreyo FO, Offiah CM. Effect of ingestion of caffeine and Dennettia tripetala (pepper fruit) seeds on peak expir- atory flow rate in a Nigerian university. Eur J Biol Med Sci Res. 2017. 5:8-13.

Oyemitan IA, Elusiyan CA, Akinkunmi EO, Obuotor EM, Akanmu MA, Olugbade TA. Memory enhancing, anticholinesterase and antimicrobial activities of $\beta$-phenylnitroethane and essential oil of Dennettia tripetala Baker f. J Ethnopharmacol. 2019. 229:256261.

Ravnskov U. Experimental glomerulonephritis induced by hydrocarbon exposure: a systematic review. BMC Nephrol. 2005. 6: 15. https://doi.org/10.1186/1471-2369-6-15

Sanzgiri UY, Srivatsan V, Muralidhara S, Dallas CE, Bruckner JV. Uptake, distribution, and elimination of carbon tetrachloride in rat tissues following inhalation and ingestion exposures. Toxicol Appl Pharmacol. 1997. 143:120-129.

Singh A, Bhat TK, Sharma OP. Clinical biochemistry of hepatotoxicity. J Clinic Toxicol. 2011. S4:001. https://doi.org/10.4172/ 2161-0495.S4-001

Timothy CO, Okere CO. Effect of Dennettia tripetela (MMIMI) seed intake on the IOP of normotensive emmetropic Nigerian Igbos. J Niger Optom Assoc. 2008. 14:14-17.

Weber LWD, Boll M, Stampfl A. Hepatotoxicity and mechanism of action of haloalkanes: carbon tetrachloride as a toxicological model. Crit Rev Toxicol. 2003. 33:105-136. 